\title{
Extent and chronology of Quaternary glaciation
}

1 Geologisches Landesamt, Billstrasse, 84, D-20539 Hamburg, Germany.E-mail: juergen.ehlers@bsu.hamburg.de

2 Cambridge Quaternary, Department of Geography, University of Cambridge, Downing Street Cambridge CB2 3EN, England.

E-mail:plg1@cam.ac.uk

In a recent INQUA project the extent of Pleistocene glaciations has been digitally mapped and the chronology of events reviewed. The onset of the present Ice Age in both hemispheres dates back to the Palaeogene. In Greenland, Iceland, North America and southernmost South America sizeable ice sheets formed well before $2.6 \mathrm{ka} \mathrm{BP.} \mathrm{In} \mathrm{Alaska} \mathrm{and} \mathrm{on} \mathrm{Tierra} \mathrm{del} \mathrm{Fuego} \mathrm{the} \mathrm{ice}$ advanced further than in any later glaciations. Evidence for Early Pleistocene glaciation (2.6-0.78 Ma) has been reported from many parts of the world, but in most cases dating remains problematic, and the size of the glaciers and ice sheets is unknown. A number of Middle Pleistocene glaciations (0.78-0.13 Ma) have been identified, mostly correlated with MIS 16, 12 and 6, including the Donian, Elsterian and Saalian of Europe. The extent of the MIS 6 glaciations is well known. Especially in Eurasia the extent of the Late Pleistocene (0.13 Ma to present) glaciations had to be revised. Major ice advances are reported for $80-100 \mathrm{ka} \mathrm{BP}, \mathrm{c.} .70-80 \mathrm{ka} \mathrm{BP}$ and c. 20 $\mathrm{ka} B P$, with the earlier glaciations being most extensive in the east. The very different shapes of the ice sheets-Donian vs Elsterian, Early vs Late Weichselian - are as yet difficult to explain and remain a challenge for climatic modellers.

\section{Introduction}

The lecture by Louis Agassiz at the Naturforschende Gesellschaft in Neuchâtel on 24 July 1837 is generally regarded as marking the birth of glacial theory. Instead of talking about fish, which was thought to be Agassiz's field of expertise, he chose to explain the origin of the erratics by glacier transport. However, it took until 1863 before the glacial theory was generally accepted in Britain and North America. At that time neither the number of glaciations nor the age of the cold stages were known. Based on their meticulous observations in the Alps, Penck and Brückner (1901/1909) concluded that all the glacial landforms they had found could be traced back to four major Pleistocene glaciations (Günz, Mindel, Riss, Würm). This view was generally accepted, and Penck and Brückner's stratigraphical scheme was applied on a global scale. Only very gradually it became clear, that the Alpine stratigraphy was not the key to all glacial sequences, and that glaciation had set in much earlier than the pioneers of Quaternary research had suspected. More and ever older glacial deposits were identified in Iceland, South America, Antarctica and Greenland. It also turned out that the sea floor held a more complete record of Pleistocene climatic history than any terrestrial sequence. Recent investigations into the distribution of marine ice-rafted debris (IRD) have shown that Northern Hemisphere glaciation began as early as
44 million years ago (Triparti et al., 2008). Greater precision in the resolution of glacial sequences has being achieved over the last two decades thanks to innovations and refinements in numerical-dating techniques, in particular for the later Middle and Late Pleistocene and throughout the Holocene.

\section{The onset of glaciation}

The onset of the present Ice Age in both hemispheres dates back to the Palaeogene. In the Miocene, glaciation became established in various mountain areas, for example in Alaska and Iceland. In most cases the traces of those early glaciations are restricted to individual sites, and only very vague limits of glaciation can be drawn. Exceptions include the Great Patagonian Glaciation in southern South America (Coronato et al., 2004) and the early glaciations in the Nebraska-Iowa area of the USA. In Alaska and in northwestern Canada the ancient ice sheets are also known to have reached beyond the limits of all later glaciations and their extent has been well mapped (Barendregt and Duk-Rodkin, 2004).

Although it had started early, glaciation in the Southern Hemisphere has always been limited by the lack of available landmass. Apart from Antarctica, only southernmost South America reached sufficiently pole-wards to allow extensive early glaciation (Figure 1). On Tierra del Fuego early ice sheets extended to the shelf edge (Coronato et al., 2004).

In the northern hemisphere, from Iceland, the oldest tillites indicate that mountain-glaciation first occurred in the Miocene (Table 1), prior to 7-6 million years ago. Subsequently almost 30 glacial events are represented since that time. There is evidence to suggest a progressive growth of glaciers during the late Pliocene (Geirsdóttir, 2004).

The oldest hint of early glaciation in Scandinavia is ice-rafted debris (IRD) in the Norwegian Sea sediments, dating from the middle Miocene. It suggests that incipient glaciations occurred on adja-

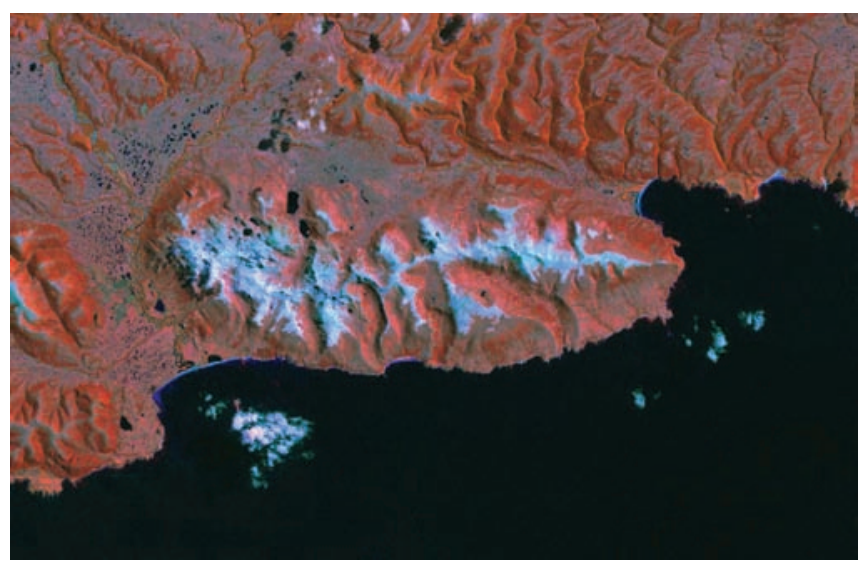

Figure 1 Landsat 7 ETM satellite image showing details of the glacial landscape in south-eastern Tierra del Fuego. (NASA Landsat Program, Landsat ETM+ scene p225r098_7p20020209_z19, USGS, Sioux Falls, of February 9th, 2002, Bands 4,7,3. Source: Global Land Cover Facility, www.landcover.org). 
Table 1 Occurrence of glaciation in Europe through the Cenozoic based on observations presented in contributions to the INQUA project, Extent and Chronology of Quaternary Glaciations' (Ehlers and Gibbard, 2004). Purple squares = glacial deposits; ? = possible glacial deposits; $\sim$ = glaciomarine sediment; MIS = Marine Isotope Stage.

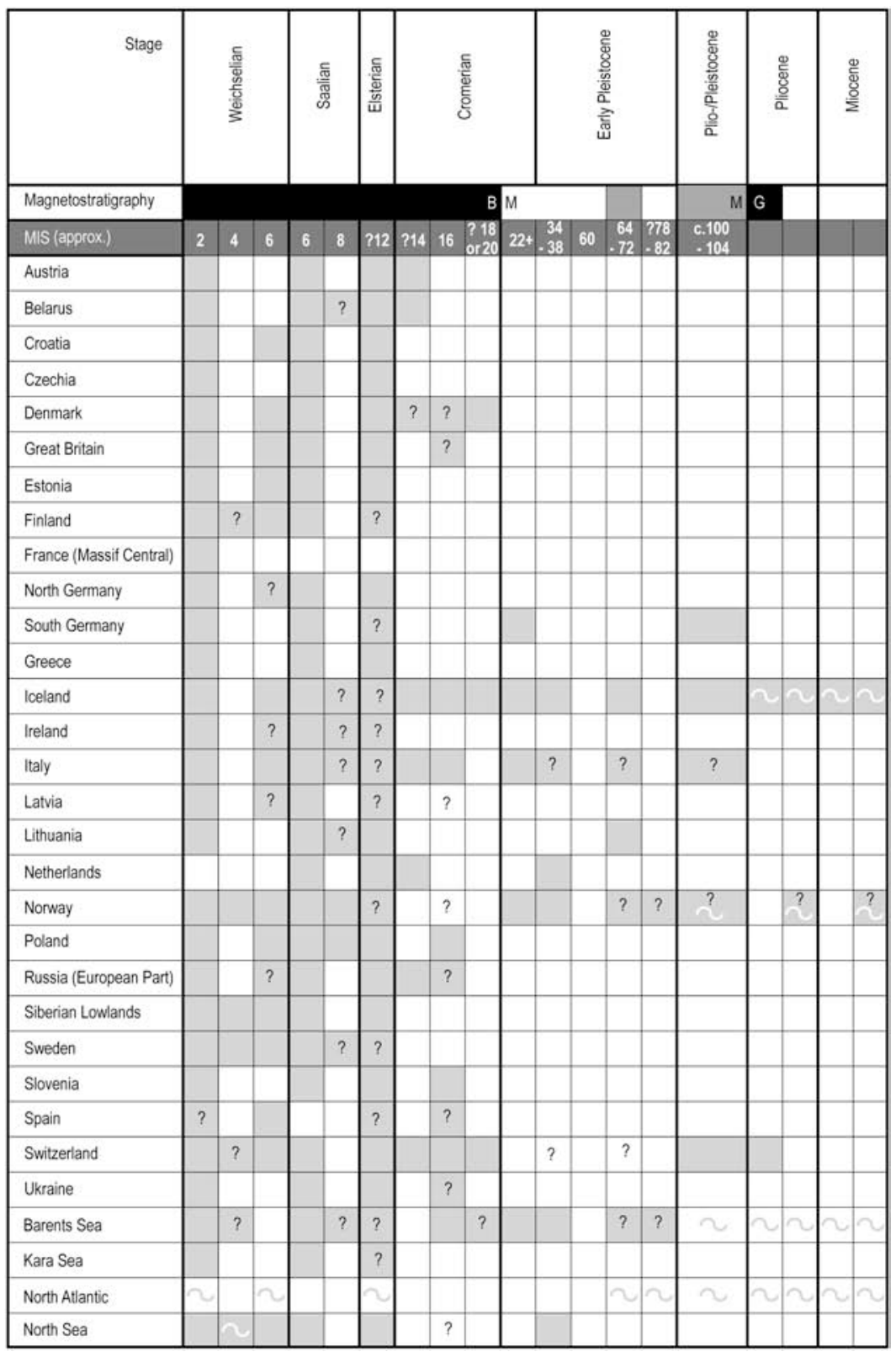

cent land areas some 12-14 Ma ago (Thiede et al., 1998). The increased supply of IRD at approximately 3.2-2.7 Ma reflects a strengthening of northern hemisphere large-scale glaciations (Jansen and Sjøholm, 1991; Mangerud et al., 1996).

\section{Early Pleistocene (2.6-0.78 Ma, MIS 103-MIS 19)}

Evidence for Early Pleistocene glaciation (2.6-0.78 Ma) has been reported from many parts of the world, but in most cases dating remains problematic, and the size of the glaciers and ice sheets is unknown. In the southern hemisphere, glaciation in New Zealand began about 2.6 million years ago and in Tasmania at about 1 million years ago (Colhoun \& Shulmeister, 2007). In the glacial maximum, the New Zealand glaciers covered about one third of the South Island
(Suggate, 2004). Early Pleistocene glaciation was widespread in southern South America (Coronato et al., 2004). In Africa two Early Pleistocene glaciation phases are reported from Mount Kenya (Mahaney, 2004).

In North America Early Pleistocene glaciation is known from northern Canada (Horton Ice Cap), and there is also evidence for the existence of a Cordilleran Ice Sheet (Barendregt \& DukRodkin, 2004). The old tills known from Kansas, Nebraska, Missouri and Iowa seem to be either older or younger (Jennings et al., 2007) (Table 2).

The most continuous record of the glacial/interglacial history of Scandinavia is probably found in the large submarine fans on the continental slope, located in front of troughs where fast-moving ice streams crossed the continental edge. However, so far no long cores have been obtained from these fans. The oldest identified and dated glacial deposit on the Norwegian shelf is the Fedje Till, that is assigned an age of about 1.1. Ma (= Marine Isotope Stage (MIS) 34-36; Sejrup et al., 2000). Also, in the Barents Sea region, initial glacial growth is reflected in a pronounced increase in the general sedimentation rate along the Svalbard margin from around 2.3-2.5 Ma. (Elverhøi et al., 1998, Vorren et al., 1998).

At what time the first ice sheets advanced beyond the limits of the Scandinavian peninsula, is still unclear. Deposits of Early Pleistocene glaciations have been reported from Denmark. At Harreskov (Jutland) early Middle Pleistocene interglacial deposits are underlain by a clay-rich diamicton, interpreted as till. The age of this oldest record of glaciation in Denmark is unknown. It might either date back to the Menapian Stage (? MIS 34-36) or, more likely, to an older part of the Cromerian Complex, i.e., ?MIS 22-19; Houmark-Nielsen, 1987; 2004). Beyond that there is only indirect evidence.

In the Netherlands the first fragments of Scandinavian rocks occur in the Harderwijk Formation, dating from almost 1.8 Ma. The Hattem Beds of the Menapian Stage (MIS 34-36: c. $1.2 \mathrm{Ma}$ ) are the oldest strata that carry major quantities of Scandinavian erratics from East Fennoscandian and central Swedish (Dalarna) source areas (Zandstra, 1983). They may be interpreted as evidence of a first major ice advance beyond the limits of the present Baltic Sea, but so far no undisputed till of that age has been found (Ehlers, 1996).

One of the key sections for the Pliocene-Pleistocene glacial and environmental events in Iceland is the Tjörnes sequence on the island's northern coast. There, in a $600 \mathrm{~m}$ thick sequence of interbedded lavas, tills, marine and terrestrial sediments, at least 14 glaciations have been recorded since 2.5-2.0 million years ago. This is probably the best preserved terrestrial record anywhere for Early and Middle Pleistocene glaciations in the North Atlantic region. The first full-scale glaciation of Iceland, with an ice sheet covering most of the island, dates back to 2.2-2.1 million years ago (Geirsdóttir, 2004).

The onset of glaciation in the Alps is still poorly understood. Part of Penck and Brückner's (1901/09) original Günz deposits are known to be reversely magnetised, and first exposure dates have yielded an age of c. 2.3 Ma (Häuselmann et al., 2007). Thus they must date back to the Matuyama Chron (i.e., pre-0.8 My). Early glaciations have also been reported from the French, Italian and Swiss parts of the mountains. However, in many cases, like with the northern Alpine Donau and Biber Stage deposits, much of the evidence is based on sediments not directly of glacial origin, and the number and extent of Early Pleistocene Alpine glaciations remain unknown.

The classical Alpine Quaternary sequence is largely a morphostratigraphy (Jerz, 1993). It is based upon the concept that the socalled 'glacial series' of landforms formed during any ice advance 
Table 2 Occurrence of glaciation in North America through the Cenozoic based on observations presented in contributions to the INQUA project, Extent and Chronology of Quaternary Glaciations' (Ehlers and Gibbard, 2004). Purple squares = glacial deposits; ? = possible glacial deposits; $\sim$ = glaciomarine sediment; MIS = Marine Isotope Stage.

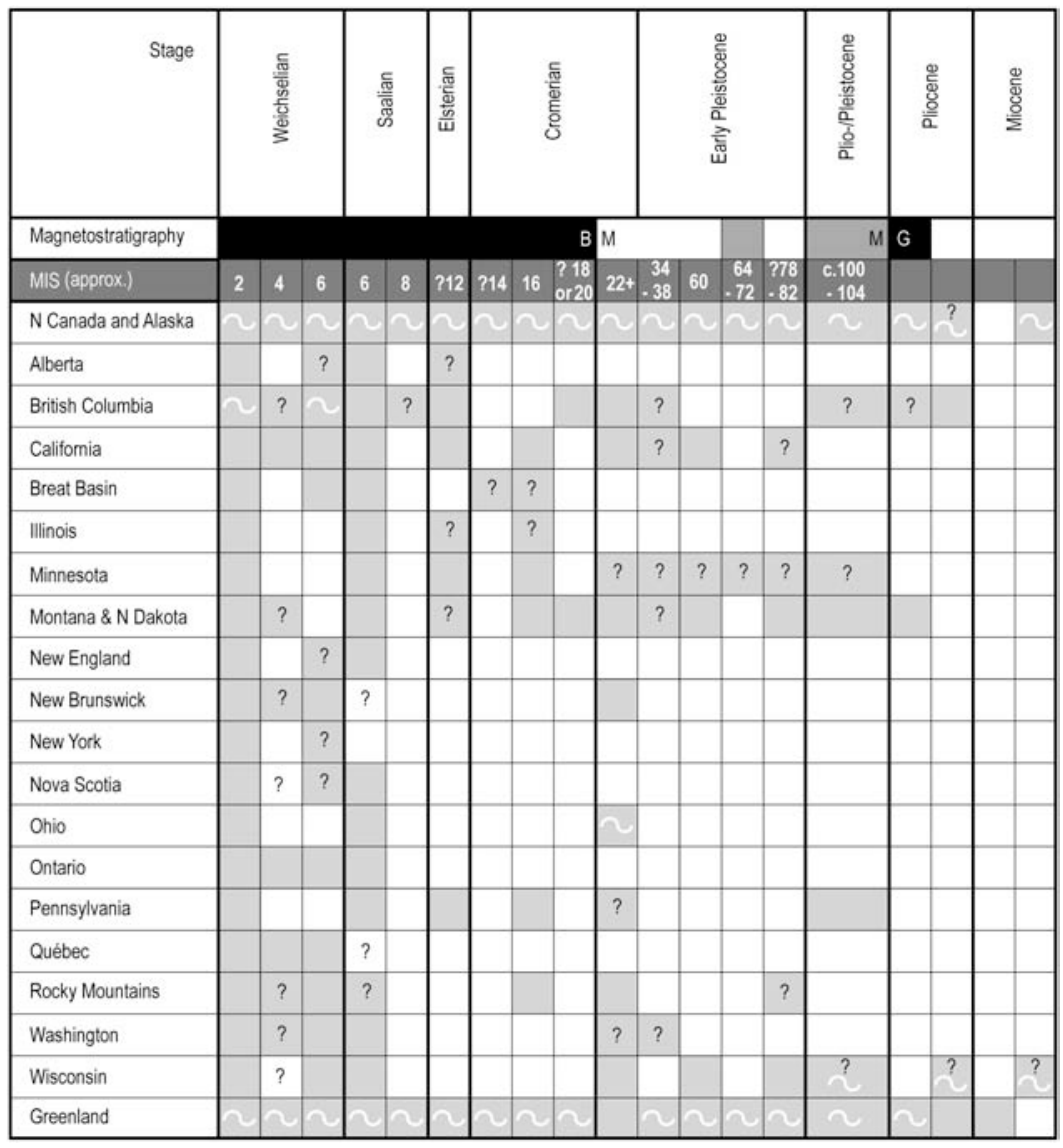

In Asia, Middle Pleistocene (MIS 6) glaciation has been reported from the northern Japanese Alps (Sawagaki et al., 2004). The high mountain ranges of Asia were glaciated in the Middle Pleistocene, and an ice cap seems to have existed at least on part of the QinghaiXizang (Tibetan) Plateau (Zhou et al., 2004).

In North America, after the collapse of the traditonal subdivision of the Pleistocene into Nebraskan, Kansan, Illinoian and Wisconsinan glaciations, many questions remain open with regard to the early Middle Pleistocene ice sheets. Apart from dating problems, there are difficulties with correlations over large distances. Therefore in some cases and the old glaciations have to be simply put together as 'pre-Illinoian' (Stiff and Hansel, 2004). Apart from fossil soils, magnetostratigraphy and dated volcanic ashes help to subdivide the glacial sequence. The 'classical Kansas' till (now Independence Formation) was found to have been deposited c. 600 to $700 \mathrm{ka}$ BP. It represents the most extensive glaciation in central North America (Jennings et al., 2007). The extent of the Illinoian glaciation (MIS 6) is clear in all areas, where the ice sheet advanced beyond the limits of the subsequent Wisconsinan glaciation, which was the case in most areas along the southern ice margin.

The oldest continental European glaciation with a widespread till sheet is Middle Pleistocene. In southern Russia, the Don lobe moraine sediment was found to be overlain by interglacial sediments bearing a fauna of the Tiraspol (Cromerian) Complex and another 4-5 interglacial palaeosols. Accordingly, the Don Glaciation (Donian Stage) is presumably c. $0.5-0.6$ ma old (postdating the Brunhes/Matuyama boundary) and relates to MIS 16 (Arkhipov et al., 1986, Astakhov, 2004). So far it has only beeen securely identified in its type region. A possible equivalent event has been suggested in Eastern England (Lee et al., 2004), this is still disputed.

The oldest glacial event that has left behind till sheets throughout northern Europe is the Elsterian

consists of a sequence of tongue basins with drumlins, moraine belts and gravel spreads. In the northern foothills of the Alps comprehensive morphological sequences of this type were initially found for only three glaciations; for the fourth this evidence was produced much later through investigations in Upper Austria. From the Early Pleistocene, the Biber and Donau glaciations no such landform assemblages have been preserved. As long as it was believed that the Alpine region was only affected by four great glaciations, morphostratigraphy seemed adequate for the tasks. However, today lithoand biostratigraphical methods are increasingly used to update the Alpine Quaternary stratigraphy and palaeomagnetic investigations contribute to an improved dating of the sedimentary record.

\section{Middle Pleistocene (0.78-0.13 Ma, MIS 19-MIS 6)}

A number of Middle Pleistocene glaciations have been identified worldwide. In New Zealand, the Waimea and Waimaunga glaciations are correlated with MIS 6 and 8. The preceding Nemona glaciation is tentatively correlated with MIS 10 (Suggate, 2004). On Tasmania so far only the Middle Pleistocene Henty glaciation has been identified (Colhoun, 2004; Fitzsimons et al., 1990). In southern South America (Patagonia) three Middle Pleistocene glaciations are distinguished (Coronato et al., 2004). Middle Pleistocene glaciations are also known from the high mountains further to the north, e.g. Columbia (Helmens, 2004) and Ecuador (Heine, 2004). Also in Africa the high mountains such as Mount Kenya were glaciated in the Middle Pleistocene (Mahaney, 2004) (Table 3).
Glaciation (MIS 12). Especially in the Netherlands and in Northwest Germany its outer limit is not yet completely clear, because it was subsequently overridden by the Saalian ice sheet and much of the evidence has been destroyed. Also in Britain, the Anglian (Elsterian) tills are the first widespread unequivocal evidence of large-scale Pleistocene glaciation. The Anglian ice sheet overrode the contemporary valley of the River Thames in southern East Anglia and also advanced into its southern tributary valleys. In northeastern Norfolk ice from both Scandinavia and the British glaciation centres interacted during the Anglian Stage. The ice sheet terminated in a large ice-dammed lake in the southern North Sea Basin (Gibbard, 2007). Although up to five different Anglian till units can be distinguished in parts of East Anglia, no evidence of a major intervening ice-free period has so far been discovered (Ehlers et al., 1991).

The Saalian Glaciation (MIS 10(?)-MIS 6) began with a nonglacial cold phase of unknown but probably rather long duration. This was interrupted by several interstadials before the continental ice sheets invaded north Germany and the Netherlands. This first, maximum Saalian ice advance is correlated with the Odranian glaciation in Poland and the Dnieper glaciation in Russia and the Ukraine. In the west, it reached the Lower Rhine and left behind enormous pushed end moraines in the Netherlands (Koster, 2005; Busschers, 2008).

In Britain, contemporaneous glaciation was similar in its extent to that during the late Pleistocene (Devensian) glaciation. Deposits from this Wolstonian Stage glaciation occur in the southern English Midlands, south of Birmingham, and in Yorkshire, Lincolnshire and the Fenland Basin. Extent of ice lobes in the North Sea basin is poorly known, but it is highly probable that British and Continental ice were confluent for a period during this phase (Carr, 2004). Con- 
Table 3 Occurrence of glaciation in the rest of the world through the Cenozoic based on observations presented in contributions to the INQUA project, Extent and Chronology of Quaternary Glaciations' (Ehlers and Gibbard, 2004). Purple squares = glacial deposits; ? = possible glacial deposits; = glaciomarine sediment; MIS = Marine Isotope Stage.

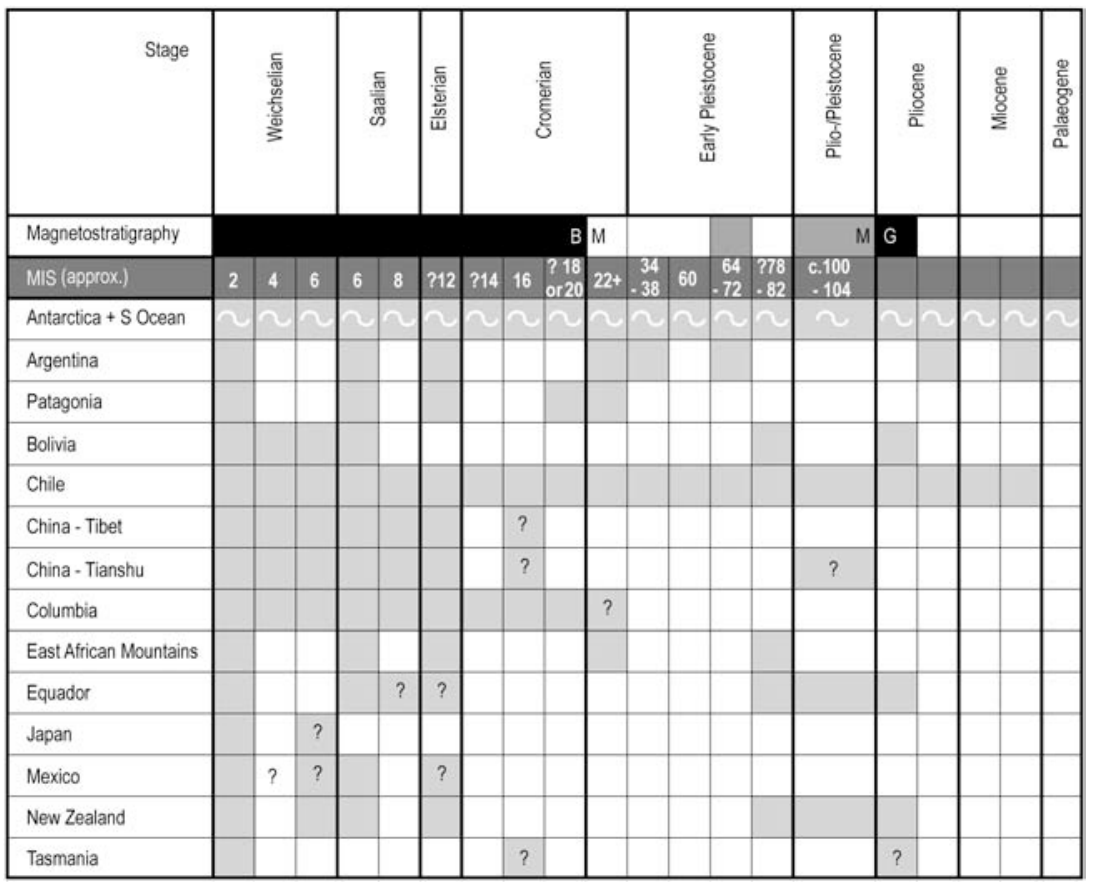

sequently a substantial ice-dammed lake again formed in the basin during this advance (Busschers, 2008).

The Samarovo glacial maximum of West Siberia is considered to be of Saalian age. However, considering the scarcity of geological information from this region, a pre-Holsteinian glaciation may well have been the most extensive in eastern Central Siberia. During the glacial maximum all northward flowing rivers were blocked, and drainage of Siberia from as far east as Lake Baikal was redirected via the Aral Sea and Caspian Sea into the Black Sea and Mediterranean, multiplying its freshwater supply. Immediately west of the Urals, the position of the ice limits is still controversial. The Saalian limit was probably positioned in the Volga-Pechora interfluve area (Ehlers et al., 2004a).

At the end of the Saalian glacial maximum the ice in Denmark and North Germany possibly melted back beyond the southern Baltic Sea coast. Later readvances in Denmark and North Germany are probably the equivalents of the Warthe (Warta) Substage. Also, the Moscow Till of Russia is the equivalent of the Polish Warta Glaciation. Towards the east, its outer limit converges with that of the Older Saalian (Dnieper) glaciation, and it may even have advanced beyond the Dnieper glacial limit.

In the Alps, the classical Günz comprises several glaciations. Part of what has been originally refererd as Günz is Early Pleistocene, part is Middle Pleistocene. Between the Günzian and the Mindelian a separate Haslach Glaciation has been postulated, based on the occurrence of distinct gravel units south of Ulm (Schreiner, 1997). However, the scarcity of early Middle Pleistocene deposits and the lack of age control make it difficult to revise this part of the classical Alpine stratigraphy. Even the stratigraphy of the Alpine Rissian cold Stage is still far from solved-at least in major parts of the glaciated area. Neither the precise extent of the glaciers, nor the number of ice advances or their age, can yet be determined with certainty (Fiebig and Preusser, 2003).

The Middle Pleistocene saw glaciations on many other high mountains, such as, for instance, in Greece (Hughes et al., 2007).

\section{Late Pleistocene and Holocene (0.13 Ma to present, MIS 1-MIS} 5)

In Australia and New Zealand the Last Glacial Maximum occurred towards the end of the Last Glaciation, shortly after 20,000 BP (MIS 2; Suggate, 2004; Colhoun, 2004). The same seems to be true for South America and the High Mountains of Africa (see various contributions in Ehlers and Gibbard, 2004c). In some regions, however, indications of earlier ice advances during the Last Glaciation have also been found, that might have occurred at MIS 5d or 4.

In North America the extent of Early and Middle Wisconsinan ice is not known. The best information is available for the Last Glacial Maximum, the Late Wisconsinan glaciation. It is now clear, that no icefree corridor existed between the Cordilleran and the Laurentide Ice Sheet. Based on numerous radiocarbon dates, the North American deglaciation history has been mapped to great detail. The Laurentide Ice Sheet reached its maximum position at about 22 ka B.P., well in advance of the Cordilleran Ice Sheet. It took until $18 \mathrm{ka}$ B.P. before the Wisconsinan ice sheets all over North America had reached their maximum (Dyke, 2004; Andrews and Dyke, 2007).

The extent of Pleistocene glaciation in Highland Asia is still a matter of debate. Kuhle's (1989) idea that the Tibetan Plateau was covered by a thick ice sheet has been refuted by other workers (Lehmkuhl and Owen, 2005). All authors agree that the Equilibrium-Line Altitudes in parts of Highland Asia were lowered by over 1000 m (Kuhle, 2004; Owen, 2007), and that glaciers were more extensive in the past, but how far this former glaciation reached is still a matter of debate. The interpretations rely heavily on the reliability of cosmogenic exposure dating.

In the 1970s through the widespread use of remote sensing data many push moraines were detected in the West Siberian and Pechora

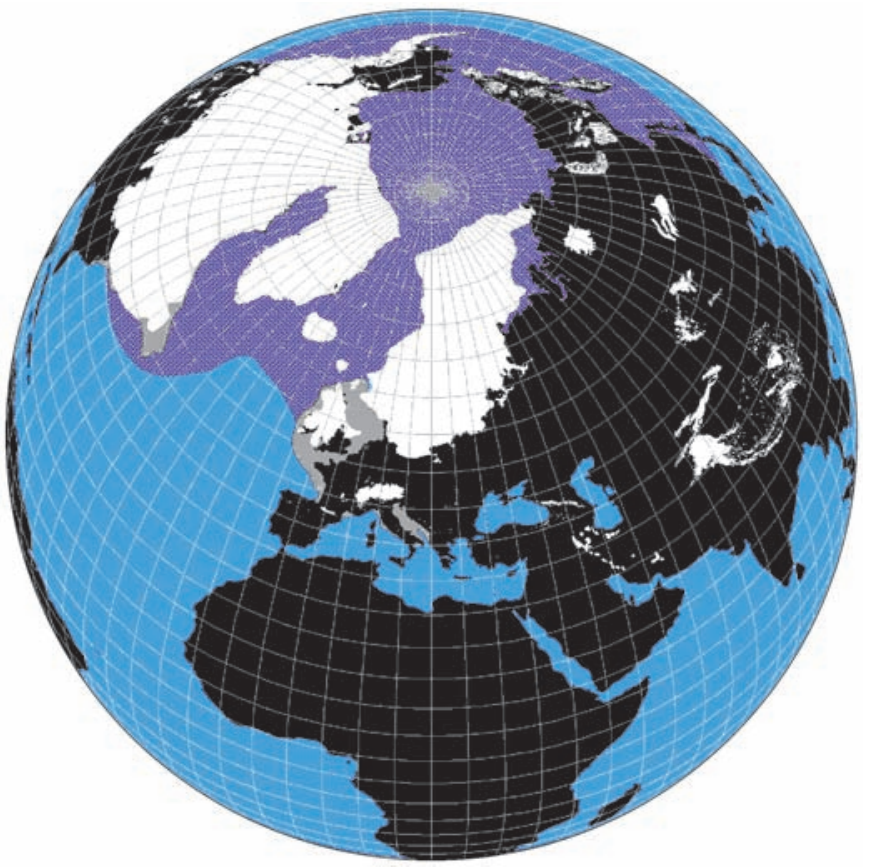

Figure 2 The maximum extent of the Northern Hemisphere LGM ice sheets (from Ehlers and Gibbard, 2004) and the approximate extent of over 0.5 months annual sea-ice cover at the LGM. 


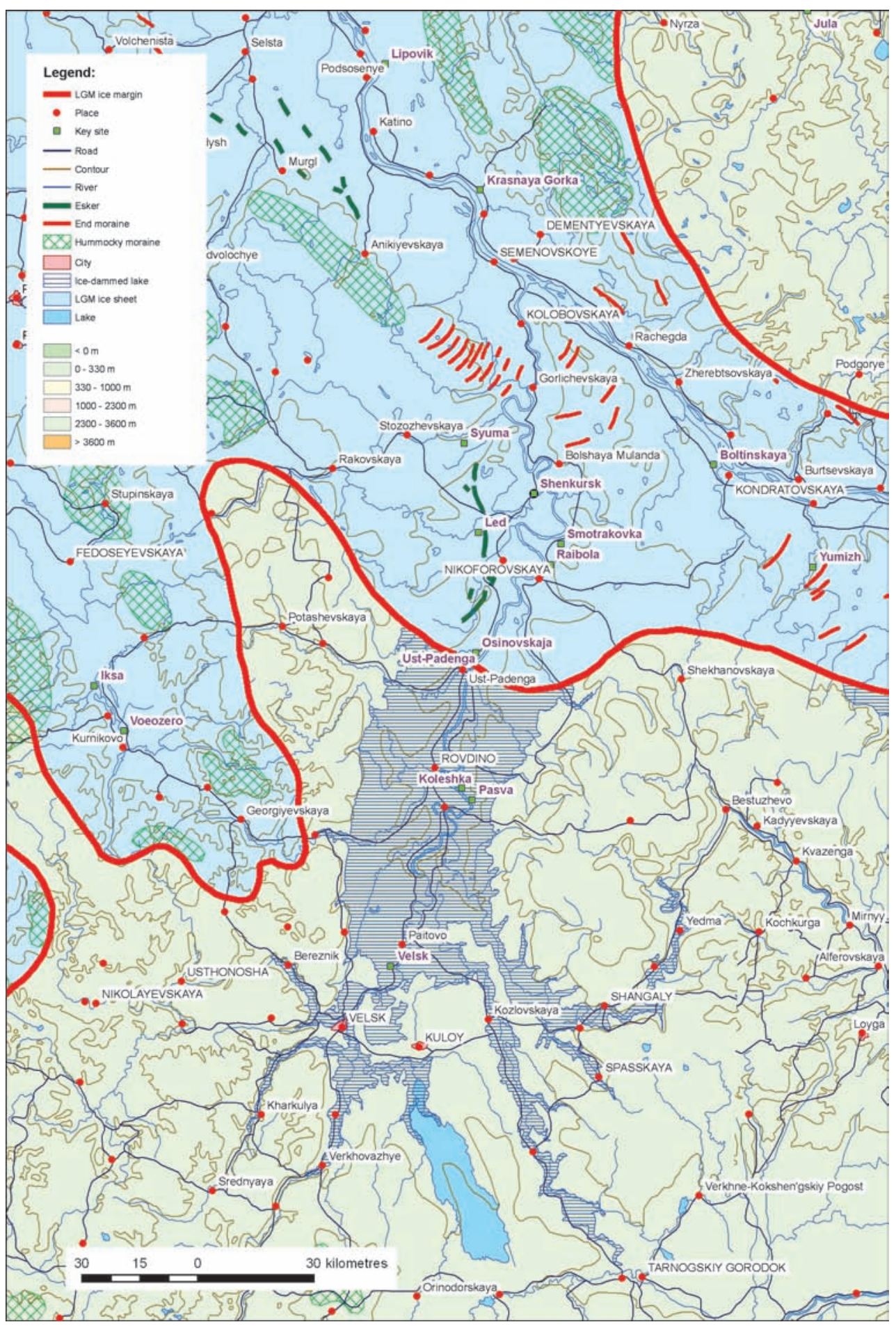

Figure 3 Extent of the Late Weichselian ice sheet in northwestern Russia. The extent of the ice lobes is controlled by the topography. Northward-flowing rivers are dammed by the ice sheet. The key sites refer to Eemian terrestrial deposits, either covered or not covered by Late Weichselian till. Excerpt from Map QL31 from Ehlers and Gibbard, 2004.

Lowlands, the configuration of which in most places contradicted the old mountain glaciation hypothesis. Obviously, a shelf-centered ice sheet had advanced onto the coastal lowlands. Northbound drainage was blocked by the advancing glaciers, forming huge ice dammed lakes. Apart from ice marginal features belonging to the vast Kara ice sheet, only traces of small alpine glaciers were found in the Polar Urals.

The first major glacial advance from the Barents and Kara seas onto the Russian mainland occurred during an early part of the
Weichselian Stage, some 80-100 ka years ago. During this glaciation a huge ice dammed lake, Lake Komi, formed over the Pechora Lowland in the European part of northern Russia. Probably an even larger ice-dammed lake existed in the West Siberian Lowland. The last ice advance that reached the mainland culminated soon after 60 $\mathrm{ka}$ and deposited the Markhida moraine, north of the Arctic Circle in the Pechora drainage basin (Svendsen et al., 2004). The assumption that the Late Weichselian ice sheet was much smaller than the penultimate glaciations was substantiated by radiocarbon dates obtained from frozen mammoth carcasses demonstrating that these northern areas were not covered by glacier ice more than 35 thousand years ago (Mangerud et al., 2002; Svendsen et al., 2004).

A major ice sheet did exist in the Barents Sea-Svalbard region at this time. However, this ice sheet did not expand onto the Russian mainland (Figure 2). Its limit was found well offshore in the Barents Sea (Mangerud et al., 2002).

The Putorana Plateau is the only part of the Russian mainland to the east of the White Sea where a sizeable ice sheet may have formed during the Late Weichselian. Several finite radiocarbon ages were obtained from beneath the inner circle of well-pronounced end morainic arcs that are ascribed to the Norilsk Stage. These moraines were deposited by outlet glaciers from an ice cap covering the mountain plateau. However, more recent investigations of the bottom sediments of Lake Lama, situated on the proximal side of the Norilsk Moraine, suggest that the lacustrine sedimentation in this basin began before the LGM. If correct, this may imply that the last coherent ice cap on the Putorna Plateau may be older than the Late Weichselian glaciation (Svendsen et al., 2004). Much new and detailed information is also available about the extent of the Scandinavian ice-sheet into Russia during the LGM (Figure 3).

The maximum ice advances of the last cold stage both in Britain and continental Europe did not occur before the last part of the Weichselian (Devensian) Stage. Nevertheless, there can be no doubt that extensive glaciers also existed in northern Europe during the Early and Middle Weichselian substages. The exact extent of those glaciations in Scandinavia, the deposits of which have been identified in Norway, Finland, and northern and central Sweden, is so far unknown. For the Middle Weichselian glaciation investigations from Finland (Salonen et al., 2008) suggest a more northeasterly dispersal centre than in the Late Weichselian glaciation (Figure 4).

According to current knowledge, the Late Weichselian glaciation of the Scandinavian Ice Sheet started around 28,000 BP. and 

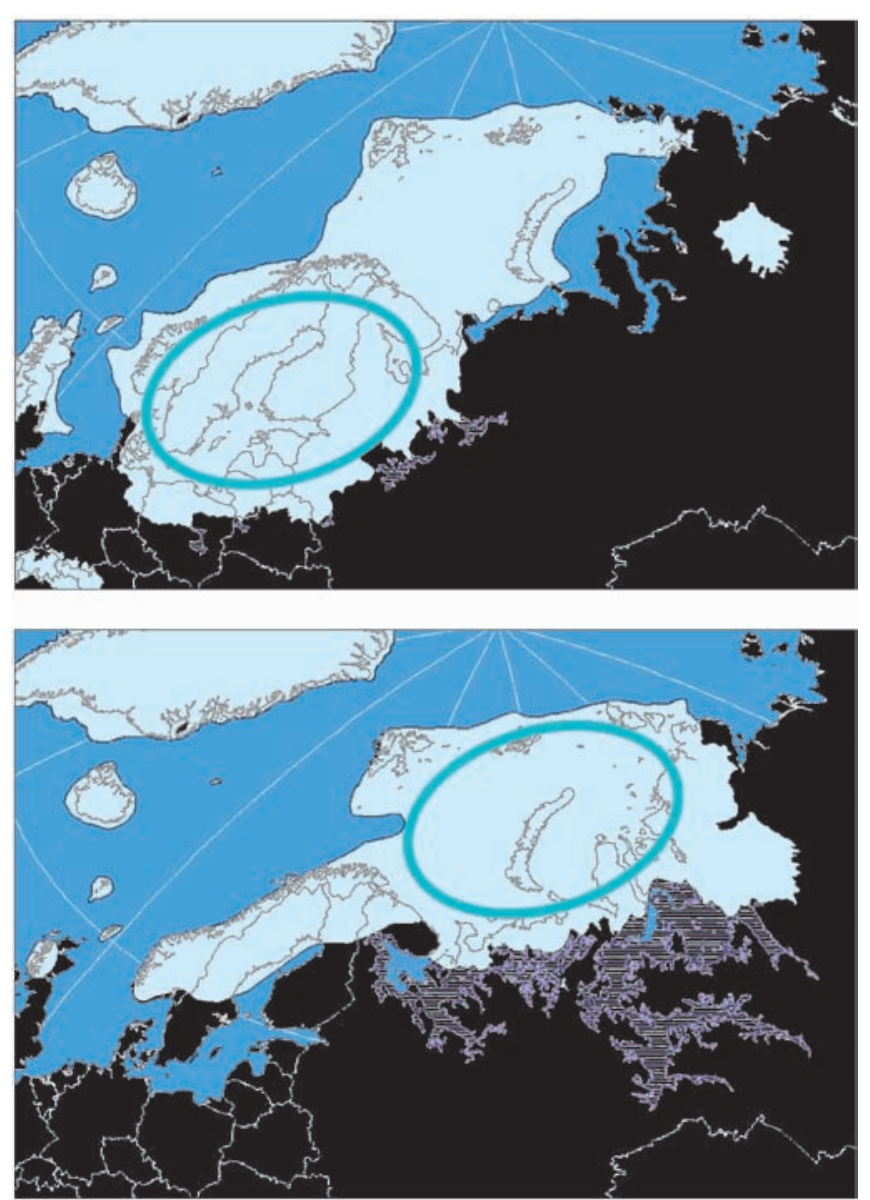

Figure 4 Comparison of the centres of the Early and Late Weichselian ice sheets. The Early Weichselian glaciation centre was positioned about $58^{\circ} \mathrm{E} / 75^{\circ} \mathrm{N}$, whilst the Late Weichselian glaciation centre was at about $20^{\circ} \mathrm{E} / 62^{\circ} \mathrm{N}$.

reached its culmination at about 22,000-18,000 BP. Radiocarbon ages from Poland suggest that it saw a very rapid, surge-like advance. The Lower Vistula region of Poland is the type region of the Vistulian (Weichselian) Glaciation (Ehlers et al., 1995). Five Vistulian till units have been identified, overlying Eemian marine deposits (MIS 5). The maximum extent of the Late Weichselian ice sheet south of the Baltic Sea is rather well mapped. The Weichselian ice did not cross the Elbe River. Three Late Weichselian ice advances can be distinguished in northeast Germany. The maximum Brandenburg Advance is assumed to have taken place at about 18,000 BP. but no precise dates are available. The Pomeranian Advance is older than 13,500 BP., whilst the Mecklenburg Advance, which is equivalent to the Fehmarn Advance of Schleswig-Holstein, is assigned to the period 13,200-13,000 BP. It thus coincides with the Oldest Dryas Chronozone (Ehlers, 1996).

During the Weichselian glacial maximum, the Baltic Sea depression did not control ice-movement directions, but the ice flowed radially from the centre to the margins. During the later Pomeranian Phase, however, ice flow was strongly controlled by the shape of the Baltic Sea depression. During this phase a Baltic ice stream advanced from the south onto the Danish Islands (Kristensen et al., 2000).

In both, Britain and Ireland, the main Devensian glaciation occurred in the later part of the cold stage (MIS 2). In Britain the Late Devensian glaciation is referred to as the Dimlington Stadial. Its glaciers advanced far south along the east coast of Britain, touching the northern coast of Norfolk. In the North Sea, the Dogger Bank remained ice-free, but major parts of the central and northern North Sea were glaciated (Kristensen et al., 2007). In the Irish Sea, ice advanced far to the south, touching the south Wales coast and possi- bly reaching as far as the Isles of Scilly. However, many details of the glacial history are still far from clear. Not only are there problems of connecting the British and Irish stratigraphic sequences with those of continental Europe, but also with one another. The last glaciation of Ireland, the Midlandian or Fenitian Glaciation, consisted of a major Irish Ice Sheet, and a smaller Kerry/Cork Ice Sheet in the southwest. The distribution of periglacial features suggests that a corridor more than $50 \mathrm{~km}$ wide between the two Irish ice sheets remained unglaciated (Knight et al., 2004).

In the Alps, a marked asymmetry is observed between glaciation of the northern and southern slopes. On the southern side of the Alps the equilibrium line altitude (ELA) is about $200 \mathrm{~m}$ higher than in the north. This contrast is further enhanced by the different altitudes of the two Alpine forelands (about $500 \mathrm{~m}$ in the north as opposed to about $100 \mathrm{~m}$ in the south). As a consequence, Quaternary glaciers have advanced far into the northern foreland of the Alps, whereas in Italy they terminated as soon as they had reached the foot of the mountains.

Initially a single undivided Würmian Glaciation was envisaged, subdivided only by a series of recessional end moraines. However, today it is quite clear that the Alps, like northern Europe and North America, experienced a Mid-Würmian and possible an Early Würmian ice advance. Only their extent is still a matter of debate (Preusser, 2004; Preusser et al., 2007).

Many of the Asian mountain ranges, such as the Werkhoyansk Mountains, the Jablonovyi or the mountains of Kamchatka have not yet been mapped in any detail. There are other formerly glaciated areas, such as the Pyrenees, the Carpathians, the Kaukasus, or the high mountains of Italy, Greece, Turkey, Iran and the Balkans which provide interesting information on former glaciation levels and equilibrium line altitudes. Comparison of the available maps with satellite imagery or a Digital Elevation Model makes it immediately clear, that much more work is needed in those areas. Remote sensing provides excellent tools to start such investigations, with imagery up to a scale of over 1:5,000 available through the QuickBird and Ikonos satellites. However, apart from all the technical progress, the decisive work to answer the open questions will still need to be done in the field.

Post-LGM ice front positions during the Late-glacial (13-10,000 ${ }^{14} \mathrm{C}$ yr BP; Hoek, this volume) and throughout the Holocene are known in great accuracy in many glaciated areas thanks to their excellent preservation and to chronological control, especially radiocarbon dating. Of particular significance is the 1,000 yr-long climatic deterioration in the Younger Dryas Chronozone $\left(11,000\right.$ and $10,000{ }^{14} \mathrm{C}$ yr BP; Hoek, this volume) during which icefront stillstand and local readvances have been mapped throughout the Northern Hemisphere glaciated regions (e.g., Andrews \& Dyke, 2007; Svendsen et al., 2004). In the Southern Hemisphere, it is not yet certain whether there is evidence of the Younger Dryas cooling. For example, age control on the Late-glacial Waiho Loop and Misery Moraines in the Southern Alps of New Zealand relies on $10 \mathrm{Be}$ exposure dating. Ivy-Ochs et al., (1999) regard the moraines as equivalents of the Northern Hemisphere Younger Dryas Stadial, whereas Shulmeister et al., (2005) disagree. Denton et al., (1999) envision a Younger Dryas cooling for southern Chile, but again the dating is not very reliable.

\section{References}

Andrews, J. T., and Dyke, A. S., 2007, Late Quaternary in North America, in Elias, S. A., ed., Encyclopedia of Quaternary Science, v. 2: Amsterdam, Elsevier, pp, 1095-1101.

Arkhipov, S. A., Isayeva, L. L., Bespaly, V. G., and Glushkova, O., 1986, Glaciation of Siberia and North-East USSR: Quaternary Science Reviews, v. 5 , no. $1-4$, pp. $463-474$.

Astakhov V., 2004, Middle Pleistocene glaciations of the Russian North: Quaternary Science Reviews, v. 23, no 11-13, pp. 1285-1311.

Barendregt, R. W., and Duk-Rodkin, A., 2004, Chronology and extent of Late Cenozoic ice sheets in North America: A magnetostratigraphic assessment, in Ehlers, J., and Gibbard, P. L., eds, Quaternary Glaciations - 
Extent and Chronology, Part II: North America, Developments in Quaternary Science, v. 2b: Amsterdam, Elsevier, pp. 1-7.

Busschers, F., 2008, Unravelling the Rhine. PhD thesis, Vrije Universiteit Amsterdam.

Colhoun, E., and Shulmeister, J., 2007, Late Pleistocene of the SW Pacific Region, in Elias, S. A., ed., Encyclopedia of Quaternary Science, v. 2: Amsterdam, Elsevier, 1066-1076.

Coronato, A.,, Martínez, O., and Jorge Rabassa, J., 2004, Glaciations in Argentine Patagonia, southern South America, in Ehlers, J., and Gibbard, P. L., eds, Quaternary Glaciations-Extent and Chronology, Part III: South America, Asia, Africa, Australasia, Antarctica: Amsterdam, Developments in Quaternary Science, v. 2c: Elsevier, pp. 49-67.

Denton, G. H., Heusser, C. J., Lowell, T. V., Moreno, P. I., Andersen, B. G., Heusser, L. E., Schlüchter, C., and Marchant, D. R., 1999: Interhemispheric linkage of palaeoclimate during the last glaciation: Geografiska Annaler, v. 81 A, pp. 107-153.

Dyke, A. S., 2004, An outline of North American deglaciation with emphasis on central and northern Canada, in Ehlers, J., and Gibbard, P. L., eds, Quaternary Glaciations-Extent and Chronology, Part II, Developments in Quaternary Science, v. 2b: North America: Amsterdam, Elsevier, pp. 373-424.

Ehlers, J., 1996, Quaternary and Glacial Geology: Chichester, Wiley.

Ehlers, J., and Gibbard, P. L. (editors) 2004a, Quaternary Glaciations - Extent and Chronology, Part I: Europe. Developments in Quaternary Science, v. 2a: Amsterdam, Elsevier.

Ehlers, J., and Gibbard, P. L. (editors) 2004b, Quaternary Glaciations - Extent and Chronology, Part II: North America. Developments in Quaternary Science, v. 2b: Amsterdam, Elsevier.

Ehlers, J., and Gibbard, P. L. (editors) 2004c, Quaternary Glaciations - Extent and Chronology, Part III: South America, Asia, Africa, Australasia, Antarctica. Developments in Quaternary Science, v. 2c: Amsterdam, Elsevier.

Ehlers, J., Astakhov, V., Gibbard, P. L., Mangerud, J., and Svendsen, J. I., 2007, Mid-Quaternary in Eurasia, in Elias, S. A., ed., Encyclopedia of Quaternary Science, v. 2, pp. 1036-1043.

Ehlers, J., Gibbard, P., and Rose, J. (eds) 1991, Glacial Deposits in Great Britain and Ireland: Rotterdam, Balkema.

Ehlers, J., Kozarski, S., and Gibbard, P. L. (eds) 1995, Glacial Deposits in North-East Europe: Rotterdam, Balkema.

Elias, S. A. (ed. ), 2007, Encyclopedia of Quaternary Science, 4 vols: Amsterdam, Elsevier.

Elverhøi, A., Hook, R. L. B., and Solheim, A., 1998, Late Cenozoic Erosion and Sediment Yield from the Svalbard-Barents Sea Region: Implications for Understanding Erosion of Glacierized Basins: Quaternary Research, v. 44, pp. 209-241.

Fiebig, M., and Preusser, F., 2003, Das Alter fluvialer Ablagerungen aus der Region Ingolstadt (Bayern) und ihre Bedeutung für die Eiszeitenchronologie des Alpenvorlandes: Zeitschrift für Geomorphologie - Neue Folge, v. 47, pp. 449-467.

Fitzsimons, S. J., Colhoun, E. A., and Van De Geer, G., 1990, Middle Pleistocene glacial stratigraphy at Baxter Rivulet, western Tasmania, Australia: Journal of Quaternary Science, v. 5, pp. 17-27.

Geirsdóttir, Á., 2004. Extent and chronology of Glaciations in Iceland; a brief overview of the glacial history, in Ehlers, J., and Gibbard, P. L., eds, Quaternary Glaciations - Extent and Chronology, Part I: Europe, Developments in Quaternary Science, v. 2a: Amsterdam, Elsevier, pp. 175-182.

Geirsdóttir, Á., and Eiríksson, J., 1994, Growth of an intermittent ice sheet in Iceland during the Late Pliocene and Early Pleistocene: Quaternary Research, v. 42, pp. 115-130.

Gibbard, P., 2007, Europe cut adrift: Nature, v. 448, pp. 259-260.

Häuselmann, P., Fiebig, M., Kubik, P.W., and Adrian, H., 2007, A first attempt to date the original "Deckenschotter" of Penck and Brückner in Bavaria: Quaternary International, v. 164-165, pp. 33-42.

Heine, K., 2004, Late Quaternary glaciations of Ecuador, in Ehlers, J., and Gibbard, P. L., eds, Quaternary Glaciations - Extent and Chronology, Part III: South America, Asia, Africa, Australasia, Antarctica, Developments in Quaternary Science, v. 2c: Amsterdam, Elsevier, pp. 165-169.

Helmens, K. F., 2004, The Quaternary glacial record of the Colombian Andes, in Ehlers, J., and Gibbard, P. L., eds, Quaternary Glaciations - Extent and Chronology, Part III: South America, Asia, Africa, Australasia, Antarctica, Developments in Quaternary Science, v. 2c: Amsterdam, Elsevier, pp. $115-134$

Houmark-Nielsen, M., 1987, Pleistocene stratigraphy and glacial history of the central part of Denmark: Bulletin of the Geological Society of Denmark, v. 36, pp. 1-189.

Houmark-Nielsen, M., 2004, The Pleistocene of Denmark: a review of stratigraphy and glaciation history, in Ehlers, J., and Gibbard, P. L., eds, Qua- ternary Glaciations - Extent and Chronology, Part I: Europe, Developments in Quaternary Science, v. 2a: Amsterdam, Elsevier, pp. 35-46.

Hughes, P. D., Woodward, J. C., and Gibbard, P. L., 2007. Middle Pleistocene cold stage climates in the Mediterranean: New evidence from the glacial record: Earth and Planetary Science Letters, v. 253, pp. 50-56.

Ivy-Ochs, S., Schlüchter, C., Kubik, P. W., and Denton, G. H., 1999: Moraine exposure dates imply synchronous Younger Dryas glacier advances in European Alps and in the Southern Alps of New Zealand: Geografiska Annaler, v. 81 A, pp. 313-323.

Jansen, E., and Sjøholm, J., 1991, Reconstruction of glaciation over the past 6 Ma based on Norwegian Sea records. Nature, v. 349, pp. 600-603.

Jennings, C. E., Aber, J. S., Balco, G., Barendregt, R., Bierman, P. R., Rovey II, C. W., Roy, M., and Mason, J. A., 2007, Mid-Quaternary in North America, in Elias, S. A., ed., Encyclopedia of Quaternary Science, v. 2, pp. 1044-1051.

Jerz, H., 1993, Das Eiszeitalter in Bayern - Erdgeschichte, Gesteine, Wasser, Boden. Geologie von Bayern, Bd. 2: Stuttgart, Schweizerbart.

Knight, J., Coxon, P., McCabe, A. M., and McCarron, S. G., 2004, Pleistocene Glaciations in Ireland, in Ehlers, J., and Gibbard, P. L., eds, Quaternary Glaciations - Extent and Chronology, Part I: Europe, Developments in Quaternary Science, Vol. 2a: Amsterdam, Elsevier, pp. 183-191.

Koster, E. A. (ed. ) 2005, The Physical Geography of Western Europe: Oxford, Oxford University Press.

Kristensen, P., Gibbard, P., Knudsen, K. L., and Ehlers, J., 2000, Last Interglacial stratigraphy at Ristinge Klint, South Denmark: Boreas, v. 29, pp. 103-116.

Kristensen, Th. B., Huuse, M., Piotrowski, J. A., and Clausen, O. R., 2007, A morphometric analysis of tunnel valleys in the eastern North Sea based on 3D seismic data: Journal of Quaternary Science, v. 22, pp. 801-815.

Kuhle, M., 1989, Die Inlandvereisung Tibets als Basis einer in der Globalstrahlungsgeometrie fußenden, reliefspezifischen Eiszeittheorie: Petermanns Geographische Mitteilungen, v. 133, no. 4, pp. 265-285.

Kuhle, M., 2004, The High Glacial (Last Ice Age and LGM) ice cover in High and Central Asia, in Ehlers, J., and Gibbard, P. L., eds, Quaternary Glaciations - Extent and Chronology, Part III: South America, Asia, Africa, Australasia, Antarctica, Developments in Quaternary Science, v. 2c: Amsterdam, Elsevier, pp. 175-199.

Lee J. R., Rose J., Hamblin R. J. O, Moorlock B. S. P., 2004, Dating the earliest lowland glaciation of eastern England: a pre-MIS 12 early Middle Pleistocene Happisburgh glaciation: Quaternary Science Reviews, v. 23, pp. $1551-1566$.

Lehmkuhl, F., and Owen, L. A., 2005, Late Quaternary glaciation of Tibet and the bordering mountains: a review: Boreas, v. 34, pp. 87-100.

Mahaney, W. C., 2004,Quaternary glacial chronology of Mount Kenya massif, in Ehlers, J., and Gibbard, P. L., eds, Quaternary Glaciations - Extent and Chronology, Part III: South America, Asia, Africa, Australasia, Antarctica, Developments in Quaternary Science, v. 2c: Amsterdam, Elsevier, pp. 227-231.

Mangerud, J., Astakhov, V., and Svendsen, J.-I., 2002, The extent of the Barents-Kara Ice Sheet during the Last Glacial Maximum: Quaternary Science Reviews, v. 21, no. 1-3, pp. 111-119.

Mangerud, J., Jansen, E., and Landvik, J., 1996, Late Cenozoic history of the Scandinavian and Barents Sea ice sheets: Global and Planetary Change, v. 12 , pp. 11-26.

Owen, L. A., 2007, Late Quaternary in Highland Asia, in Elias, S. A., ed., Encyclopedia of Quaternary Science, v. 2: Amsterdam, Elsevier, 1109-1116.

Pedersen, S. A. S., 2005, Structurtal analysis of the Rubjerg Knude Glaciotectonic Complex, Vendsyssel, northern Denmark: Geological Survey of Denmark and Greenland Bulletin, v. 8, 192 pp.

Penck, A. \& Brückner, E., 1901/1909, Die Alpen im Eiszeitalter, 3 vols: Leipzig, Tauchnitz.

Salonen, V.-P., Kaakinen, A., Kultti, S., Miettinen, A., Eskola, K., and Lunkka, J.-P., 2008, Middle Weichselian glacial event in the central part of the Scandinavian Ice Sheet recorded in the Hitura pit, Ostrobothnia, Finland: Boreas, v. 37, pp. 38-54.

Sawagaki, T., Aoki, T., Hasegawa, H., Iwasaki, S., Iwata, S., and Hirakawa, K., 2004, Late Quaternary glaciations in Japan, in Ehlers, J., and Gibbard, P. L., eds, Quaternary Glaciations - Extent and Chronology, Part III: South America, Asia, Africa, Australasia, Antarctica, Developments in Quaternary Science, v. 2c: Amsterdam, Elsevier, pp. 217-225.

Schreiner, A., 1997, Einführung in die Quartärgeologie, 2nd ed.: Stuttgart, Schweizerbart.

Shulmeister, J., Fink, D., and Augustinus, P. C., 2005: A cosmogenic nuclide chronology of the last glacial transition in North-West Nelson, North Westland, New Zealand: Quaternary Science Reviews, v. 24, pp. 2207-2227. 
Sejrup, H.-P., Larsen, E., Landvik, J., King, E. L., Haflidason, H., and Nesje, A., 2000, Quaternary glaciations in southern Fennoscandia: evidence from southwestern Norway and the North Sea region: Quaternary Science Reviews, v. 19, pp. 667-685.

Stiff, B. J., and Hansel, A. K., 2004, Quaternary Glaciations in Illinois, in Ehlers, J., and Gibbard, P. L., eds, Quaternary Glaciations - Extent and Chronology, Part II: North America, Developments in Quaternary Science, v. 2b: Amsterdam, Elsevier, pp. 71-82.

Suggate, R. P., 2004, South Island, New Zealand; ice advances and marine shorelines, in Ehlers, J., and Gibbard, P. L., eds, Quaternary Glaciations Extent and Chronology, Part III: South America, Asia, Africa, Australasia, Antarctica, Developments in Quaternary Science, v. 2c: Amsterdam, Elsevier, pp. 285-291.

Svendsen, J. I., Alexanderson, H., Astakhov, V. I., Demidov, I., Dowdeswell, J. A., Funder, S., Gataullin, V., Henriksen, M., Hjort. C., HoumarkNielsen, M., Hubberten, H. W., Ingólfsson, Ó., Jakobsson, M., Kjær, K. H., Larsen, E., Lokrantz, H., Lunkka, J. P., Lyså, A., Mangerud, J., Matiouchkov, A., Murray, A., Möller, P., Niessen, F., Nikolskaya, O., Polyak, L., Saarnisto, M., Siegert, C., Siegert, M. J., Spielhagen, R. F., Stein, R., 2004, Late Quaternary ice sheet history of Northern Eurasia: Quaternary Science Reviews, v. 23, no. 11-13, pp. 1229-1271.

Syverson, K. M., and Colgan, P. M., 2004, The Quaternary of Wisconsin: a review of stratigraphy and glaciation history, in Ehlers, J., and Gibbard, P. L., eds, Quaternary Glaciations - Extent and Chronology, Part II: North America, Developments in Quaternary Science, v. 2b: Amsterdam, Elsevier, pp. 295-311.

Thiede, J., Winkler, A., Wolf-Welling, T., Eldholm, O., Myhre, A. M., Braumann, K.-H., Henrich, R., and Stein, R., 1998, Late Cenozoic History of the Polar North Atlantic: Results from Ocean Drilling: Quaternary Science Reviews, v. 17, pp. 185-208.

Tripati, A., Eagle, R., Morton, A., Dowdeswell, J., Atkinson, K., Bahe, Y., Dawber, C., Khadun, E., Shaw, R., Shorttle, O., and Thanabalasundaram, L., 2008, Evidence for Northern Hemisphere glaciation back to $44 \mathrm{Ma}$ from ice-rafted debris in the Greenland Sea: Earth and Planetary Science Letters, v. 265, pp. 112-122.

Vázquez-Selem, L., and Heine, K., 2004, Late Quaternary glaciation of México, in Ehlers, J., and Gibbard, P. L., eds, Quaternary Glaciations - Exten and Chronology, Part III: South America, Asia, Africa, Australasia Antarctica, Developments in Quaternary Science, v. 2c: Amsterdam, Elsevier, pp. 233-242.

Vorren. T. O., Laberg, J. S., Blaumme, F., Dowdeswell, J. A., Kenyon, N. H., Mienert, J., Rumohr, J., and Werner, F., 1998, The Norwegian-Greenland Sea Continental Margins: Morphology and Late Quaternary Sedimentary Processes and Environment: Quaternary Science Reviews, v. 17, pp. 273-202.

Zandstra, J. G., 1983, Fine gravel, heavy mineral and grain-size analyses of Pleistocene, mainly glacigenic deposits in the Netherlands, in Ehlers, J., ed., Glacial Deposits in North-West Europe: Rotterdam, Balkema, pp. 361-377.
Zhou, S. Z., Jujun, L., Zhang, S. Q., Zhao, J.D., and Cui, J.X., 2004, Quaternary glaciations in China, in Ehlers, J., and Gibbard, P. L., eds, Quaternary Glaciations - Extent and Chronology, Part III: South America, Asia, Africa, Australasia, Antarctica, Developments in Quaternary Science, v. 2c: Amsterdam, Elsevier, pp. 105-113.

Jürgen Ehlers, Geologisches Landesamt Hamburg, Germany, Head of the mapping department. 1974 Diploma and 1978 Ph.D. in Geography at Hamburg University, 1989 Habilitation at University of Bremen. Publications include over 75 papers, 19 books, numerous reports and reviews on Quaternary geology and coastal morphology. Together with Phil Gibbard (Cambridge) published the INQUA Project 'Extent and Chronology of Quaternary Glaciations'.

Philip Gibbard is Professor of Quaternary Palaeoenvironments at the University of Cambridge, United Kingdom, and chair of the International Commission on Stratigraphy's Subcommission on Quaternary Stratigraphy. He is also a member, and was formerly Secretary, of the Stratigraphy and Geochronology Commission of INQUA, the INQUA Subcommission of European Quaternary Stratigraphy and the Geological Society of London's Stratigraphy Commission. His research is focused on terrestrial and shallow marine sedimentation, stratigraphy and environmental evolution throughout Europe, but he has also worked in the Arctic, North America and South-East Asia.
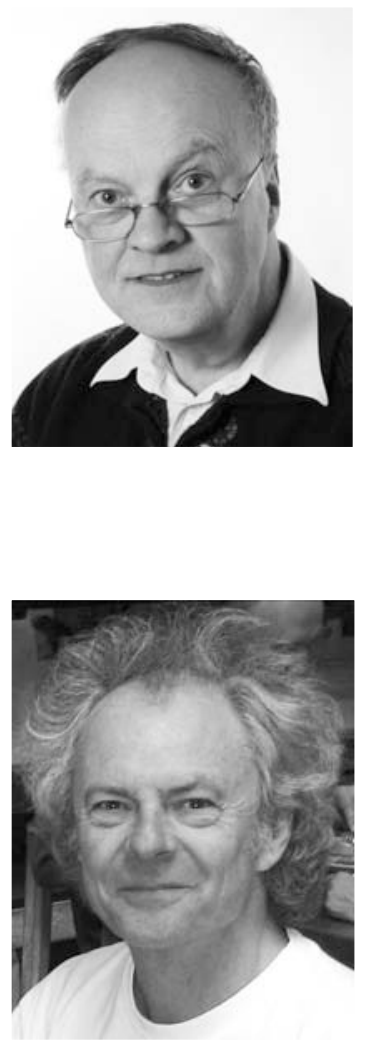